\title{
KARAKTERISTIK SEBARAN SEDIMEN PANTAI UTARA JAWA STUDI KASUS: KECAMATAN BREBES JAWA TENGAH
}

\author{
DISTRIBUTION AND CHARACTERISTIC OF SEDIMENT AT JAVA \\ NORTHERN COASTAL CASE STUDY: BREBES SUBDISTRIC CENTRAL JAVA
}

\author{
Wisnu A. Gemilang, Ulung J. Wisha, Guntur A. Rahmawan \\ dan Ruzana Dhiauddin
}

Loka Riset Sumber Daya dan Kerentanan Pesisir

JL. Raya Padang Painan km.16, Bungus, Padang e-mail : wisnu.gemilang@yahoo.co.id

Diterima tanggal: 10 Januari 2018 ; diterima setelah perbaikan: 02 April 2018 ; Disetujui tanggal: 15 Agustus 2018

\begin{abstract}
ABSTRAK
Dinamika kawasan pesisir mencakup proses erosi dan sedimentasi merupakan hal penting untuk mengetahui kondisi pantai. Pesisir Kecamatan Brebes merupakan salah satu kawasan di Pantai Utara Pulau Jawa yang memiliki dinamika perubahan pesisir sangat fluktuatif. Studi sebaran jenis sedimen yang dilakukan secara terpadu di perairan Kecamatan Brebes ditunjukkan untuk memberikan gambaran proses transportasi dan pengendapan sedimen berdasarkan distribusi ukuran butir sedimen. Penelitian dilakukan dengan pengambilan sampel sedimen dasar perairan secara acak dan tersebar di sepanjang pesisir dengan metode grab sampler, kemudian dilakukan analisis lebih lanjut dengan metode granulometri. Hasil penelitian menunjukkan bahwa secara umum, pola sebaran sedimen permukaan dasar laut Kecamatan Brebes didominasi oleh sedimen berukuran lempung-pasir. Jenis sedimen berdasarkan ukuran butirnya yaitu pasir, pasir lanauan, lanau pasiran dan lanau. Kondisi hidrooseanografi yang fluktuatif memberikan nilai sortasi buruk hingga sedang. Dominasi ukuran halus tersebar pada bagian Timur wilayah kajian, sedangkan fraksi kasar tersebar dibagian Barat dekat dengan laut Jawa. Kondisi tersebut menjadi faktor utama yang memicu erosi dibagian pesisir Kecamatan Brebes.
\end{abstract}

Kata kunci: Sebaran sedimen, pantai utara Jawa, Kecamatan Brebes, erosi, granulometri.

\begin{abstract}
Coastal dynamics such as sedimentation and erosion are significance to determine the coastal condition. Brebes Subdistrict's is one of areas located in the Java North Coast where the coastal changes are fluctuative. Integrated study of sediment distribution in this area is aimed to illustrate the sediment transport and deposition process according to the grain size distribution. This study was done by collecting the sea bed sample sediment along the coast randomly using grab sampler. The sediment sampled was then analyzed by employing granulometry analysis. Generally, the sediment distribution of the surface bottom is dominated by clay - sand size. Based on its grain size, sediment types are classified into sand, silty sand, sandy silt and silt. Hydro-oceanography condition which are very fluctuative influences the sediment sortation value (poorly sorted-moderately sorted). Fine sand predomination is found eastward of study area, whilst, coarse sediment separated westward near the Java Sea. Those conditions have a significance role evoking erosion in the Brebes coastal area.
\end{abstract}

Keywords: Sedimen distribution, Java northern coastal, Brebes subdistrict, erosion, granulometry. 


\section{PENDAHULUAN}

Muara adalah bagian pertemuan antara laut dan lingkungan darat. Pengendapan berupa fraksi lumpur halus yang terjadi sebagai akibat dari interaksi antara arus, pasang-surut dan salinitas. Oleh karena itu muara merupakan lingkungan pertukaran terbatas yang dapat bertindak sebagai buangan atau sumber sedimen dan sedimen berasosiasi dengan kontaminan dibuang ke lingkungan perairan (Rainey et al., 2003). Interpretasi lingkungan dari distribusi ukuran butir ditemukan dalam deposit sedimen dan masih merupakan tujuan dasar sedimentologi (McLaren \& Bowles. 1985). Pengetahuan tentang karakteristik tekstur sedimen muara sangat penting dalam membedakan berbagai pengendapan mikro lingkungan (Ganesh et al., 2013). Proses pengendapan sedimen dapat diperkirakan melalui penyebaran ukuran butir sedimen (Nugroho et al., 2014). Sifat-sifat sedimen yang penting untuk diketahui antara lain ukuran partikel dan butir sedimen, rapat massa, bentuk dan juga kecepatan sedimen (Bayhaqi et al., 2015).

Ukuran butir adalah aspek yang paling fundamental dari partikel sedimen, yang mempengaruhi proses sedimentasi, transportasi dan pengendapan (Blott et al., 2001). Analisis ukuran butir karena itu memberikan petunjuk penting asal sedimen, sejarah transportasi dan kondisi pengendapan (e.g. Folk \& Ward, 1957; Friedman, 1979; Bui et al., 1990). Distribusi ukuran butir dipengaruhi oleh faktor lain seperti jarak dari garis pantai, jarak dari sumber (sungai), sumber material sedimen, topografi dan mekanisme transportasi sedimen (Abuodha, 2003). Analisis granulometri adalah analisis ukuran butir sedimen. Analisis ini umumnya dilakukan untuk menentukan tingkat resistensi terhadap proses eksogenik butir sedimen, Sebagai contoh yaitu proses pelapukan, erosi, dan abrasi dari asalnya trasnportasi dan proses deposisi sedimen (Yasin et al., 2016).

Faktor oseanografi yang berperan dalam distribusi sedimen di suatu perairan adalah arus, khususnya terhadap sedimen tersuspensi (suspended sediment) (Purnawan et al., 2012). Hal ini senada dengan Darlan (1996) yang menyebutkan bahwa distribusi fraksi sedimen dipengaruhi oleh arus. Mekanisme distribusi pasir ini sangat tergantung dari dua faktor yang saling bergantung yaitu penyortiran hidrolik (hydrolic sorting) dan pengendapan (Wenno \& Witasari, 2001). Dalam lingkungan pesisir, sedimen bersifat dinamis yang akan mengalami pengikisan, transportasi dan pengendapan dalam skala spasial maupun temporal.
Penyelidikan pemahaman tentang proses dinamis yang terjadi di lingkungan pesisir sangatlah diperlukan untuk prediksi evolusi pesisir dimasa datang (Winter, 2007). Ardani (2004) menyatakan bahwa selama periode tahun 1991 - 2002, abrasi yang terjadi di pesisir Brebes seluas 696.848 ha atau lebih kurang 63.350 ha/tahun dan akresi seluas 115.847 ha atau 101.441 ha/tahun.

Perairan pantai Brebes merupakan pantai dangkal tersusun dari dataran alluvial akibat beberapa aktivitas sungai besar dan kecil yang bermuara di perairan tersebut. Perubahan sifat sungai baik di hulu maupun hilir mempengaruhi kondisi pantai termasuk terjadinya abrasi dan akresi pantai. Mangrove umumnya dijumpai di muara sungai berasosiasi dengan dataran lumpur dan pasir pantai (Dinas Kelautan dan Perikanan Provinsi Jawa Tengah, 2012). Penelitian yang pernah dilakukan pada pesisir Kecamatan Brebes yaitu laju sedimentasi di perairan Kecamatan Brebes Jawa Tengah menggunakan metode isotop unsupported $210 \mathrm{~Pb}$ hanya memberikan gambaran karakteristik pengendapan sedimen secara vertikal (Gemilang et al., 2017). Pada artikel kali ini, fokus pembahasannya adalah untuk mendeskripsikan karakteristik sebaran sedimen secara lateral berdasarkan hasil analisis granulometri, statistik sedimen dan digambarkan secara spasial sehingga dapat memberikan gambaran sumber sedimen, proses transportasi dan deposisi sedimen di perairan Kecamatan Brebes.

\section{BAHAN DAN METODE}

Pantai Kabupaten Brebes umumnya cenderung landai dengan kelerangan $0-0,2 \%$. Di wilayah pantai (pesisir) Kabupaten Brebes terdapat beberapa sungai besar yaitu Sungai Kaligangsa, Sungai Pemali, Kali Nipon, Kali Beting, Kali Kluwut, Kali Kabuyutan dan Sungai Cisanggarung (Dinas Kelautan dan Perikanan Kabupaten Brebes, 2008). Kondisi geologi dan stratigrafi Kecamatan Brebes menurut (Djuri et al., 1996) tersusun atas Qa (endapan alluvial) yang menyusun bagian pesisir dan dataran rendah di kecamatan Brebes terdiri dari kerikil, pasir, lanau dan lempung sebagian endapan sungai dan pantai. Bagian Selatan Kecamatan Brebes tersusun atas Qls (endapan lahar Gunung Slamet), Tptl (Anggota Batugamping $F m$. Tapak), Tmp (Fm. Pemali) tersusun atas napal bersisipan batugamping pasiran dan batupasir kasar.

Penelitian ini berlokasi di perairan mulai dari muara sungai hingga menuju ke arah laut lepas yang ada di Kecamatan Brebes, Jawa Tengah. Pengambilan sampel dilakukan pada 01-02 April 2016 dengan jumlah titik 
pengambilan sampel sebanyak 26 titik yang tersebar secara merata dari bagian Timur hingga Barat daerah penelitian (Gambar 1). Kondisi pasang-surut selama pengambilan sampel (Gambar 2) dilakukan pada saat kondisi pasang purnama, yang mewakili saat elevasi maksimal dan minimal dari elevasi muka air laut.

Pengambilan sampel berdasarkan pada pembagian morfologi pesisir yaitu muara sungai, bagian depan beting gisik dan laut lepas untuk mengetahui masingmasing karakteristik sedimen tiap lokasi pengambilan sampel. Kedalaman lokasi pengambilan sampel dilakukan pada kisaran kedalaman 0,5m-4m. Analisis granulometri dilakukan di laboratorium sedimen Pusat Penelitian dan Pengembangan Geologi Laut (P3GL) Cirebon selama 15 hari analisis.

Metode penelitian yang digunakan ialah metode deskriptif. Metode pengambilan sampel sedimen dasar menggunakan metode purposive sampling. Pengambilan sampel sedimen dasar menggunakan alat eckman grab sampler sehingga memungkinkan sampel sedimen bagian dasar terperangkap pada alat tersebut. Metode analisis ukuran butir dan jenis sedimen menggunakan metode ayak kering pada saringan bertingkat (sieve analysis) serta analisis granulometri.

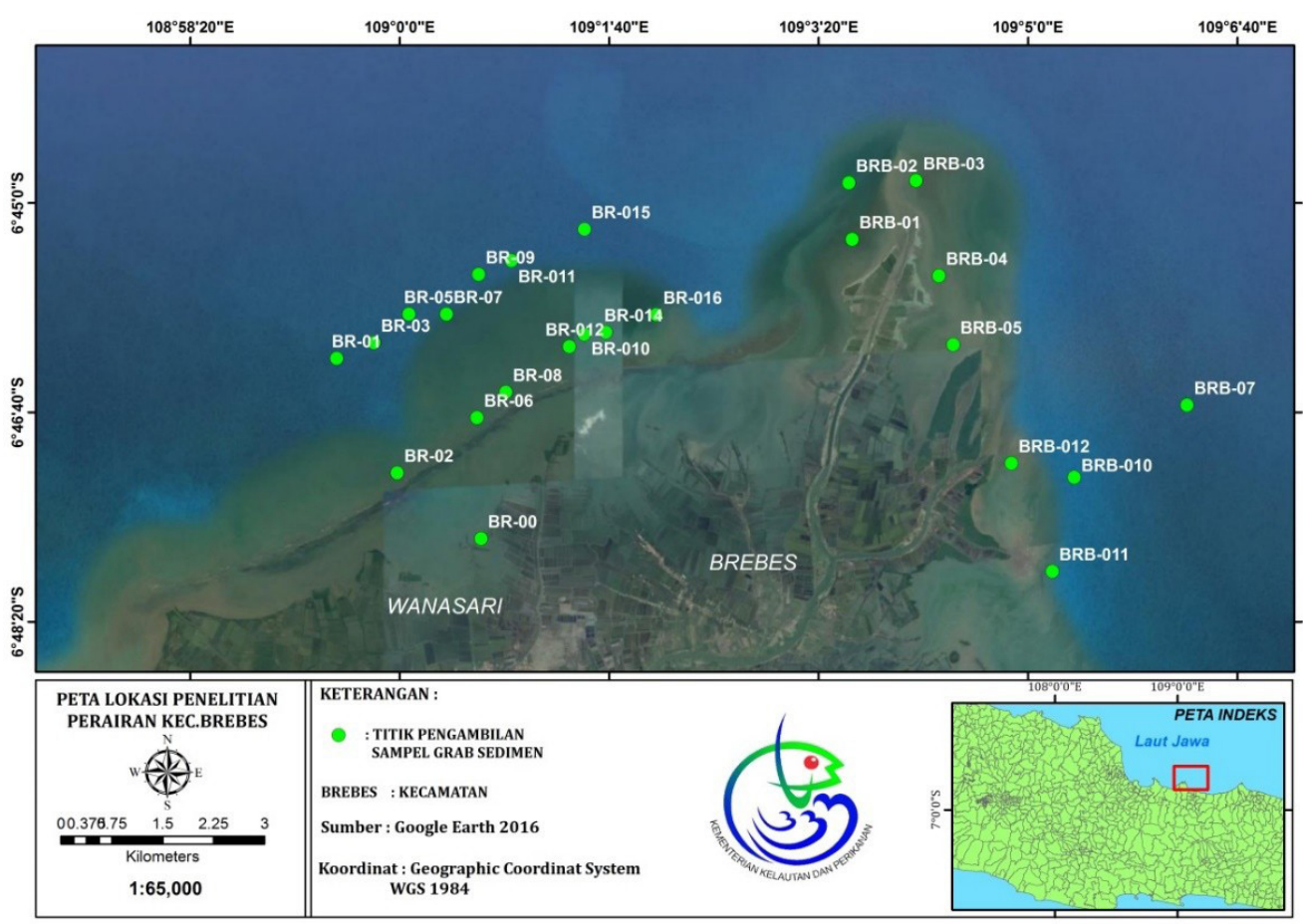

Gambar 1. Peta lokasi penelitian.

Figure 1. The map of study area.

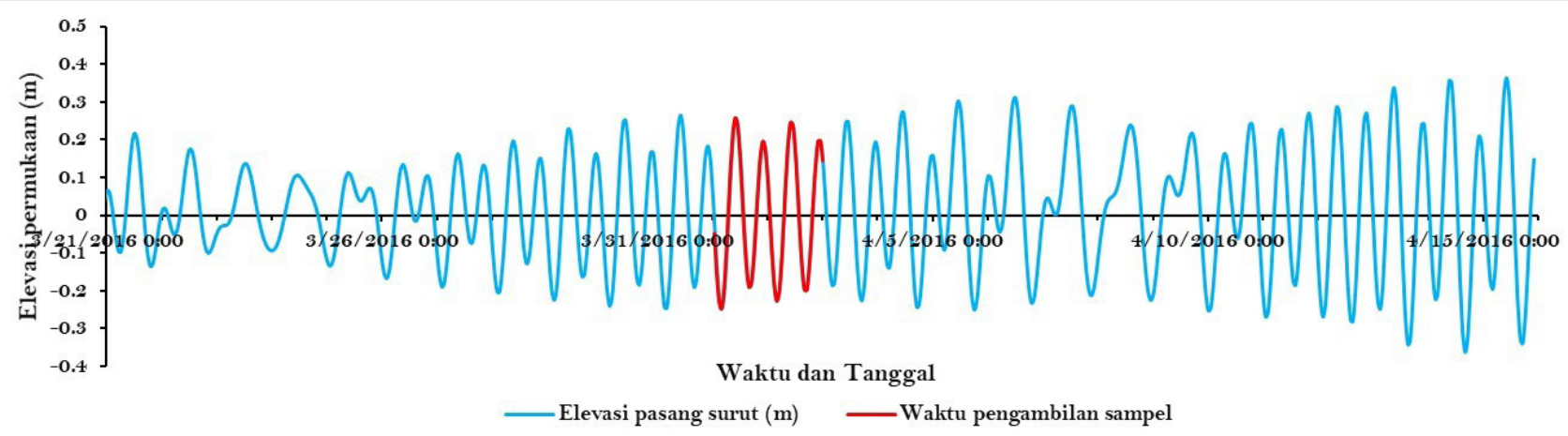

Gambar 2. Grafik pasang-surut saat pengambilan sampel.

Figure 2. Tidal condition during sampling time. 
Distribusi ukuran butir diketahui menggunakan metode granulometri (Hubbard \& Pocock, 1972; Hsieh, 1995).

Pemisahan ukuran butir dilakukan dengan saringan berukuran; $>2 ; 1,4 ; 1 ; 0,5 ; 0,250 ; 0,150 ; 0,090 ; 0,063$; dan $<0.063 \mathrm{~mm}$. Klasifikasi ukuran butir dilakukan berdasarkan klasifikasi Wentworth (1992). Penentuan jenis sedimen dilakukan berdasarkan klasifikasi Diagram Segitiga Shepard tahun 1954 (Dyer, 1986), sedangkan untuk menafsirkan sebaran, mekanisme pengangkutan dan pengendapan sedimen digunakan pendekatan statistik dari masing-masing kelompok sedimen. Analisis statistik sedimen berupa sorting, skewnees dan kurtosis menggunakan klasifikasi Flok \& Ward, 1957, sedangkan perhitungannya menggunakan Software Microsoft Excel 2007 untuk menghitung persentase ukuran butir dan statistik sedimen.

\section{HASIL DAN PEMBAHASAN}

\section{Jenis Sedimen Perairan Kecamatan Brebes}

Penelitian sebelumnya pada tahun 2015 terkait jenis sedimen dasar perairan yang ada di Kabupaten Brebes secara keseluruhan adalah berjenis pasir dan lanau. Jenis sedimen lanau sangat mendominasi perairan yang ada di Kabupaten Brebes (Apriyantoro et al., 2016). Data ukuran butir berdasarkan 26 sampel yang diambil dari perairan Kecamatan Brebes. Sampel sedimen yang telah dianalisis oleh dengan metode granulometri (ukuran butir sedimen) memperlihatkan variasi nilai dan persentase ukuran butir sedimen.
Hasil analisis terhadap persentase ukuran butir sedimen dapat dilihat pada Diagram Segitiga Shepard 1954 (Gambar 4), sehingga dapat memudahkan untuk menginterpretasikan pengelompokan jenis sedimennya Secara umum sedimen dasar laut yang ada di lokasi penelitian didominasi oleh ukuran lanau hingga pasir (Gambar 3). Penamaan jenis sedimen berdasarkan pengklasifikasian pada Diagram Segitiga Shepard 1954. Secara umum berdasarkan persentase ukuran butir sedimen dapat terlihat bahwa jenis sedimen yang ada di perairan Kecamatan Brebes terbagi atas 4 jenis sedimen berdasarkan persentase ukuran butir sedimen yaitu silt (lanau), sand (pasir), sandy silt (lanau pasiran), silty sand (pasir lanauan). Dominasi jenis sedimen lanau hingga lanau pasiran tersebar pada bagian Timur daerah penelitian yang merupakan bagian perairan laut yang berdekatan dengan muara sungai utama yang ada di Kecamatan Brebes yaitu Sungai Pemali dan Sungai Codetan.

Kelompok jenis sedimen pasir, pasir lanauan hingga pasir lumpuran tersebar pada bagian Barat dasar perairan daerah penelitian. Bagian Barat daerah penelitian merupakan daerah yang memiliki morfologi beting gisik atau sering disebut sebagai Pulau Pasir oleh warga setempat yang berhadapan langsung dengan laut lepas, namun pada bagian batasan Barat daerah penelitian juga terdapat Muara Sungai Nipon.

Kecepatan arus datang pada daerah penelitian berasal dari arah Barat Laut dengan kecapatan mencapai $0,78 \mathrm{~m} /$ detik, namun di wilayah sekitar muara Pemali berkisar antara 0,05-0,15 m/detik. Kecapatan arus

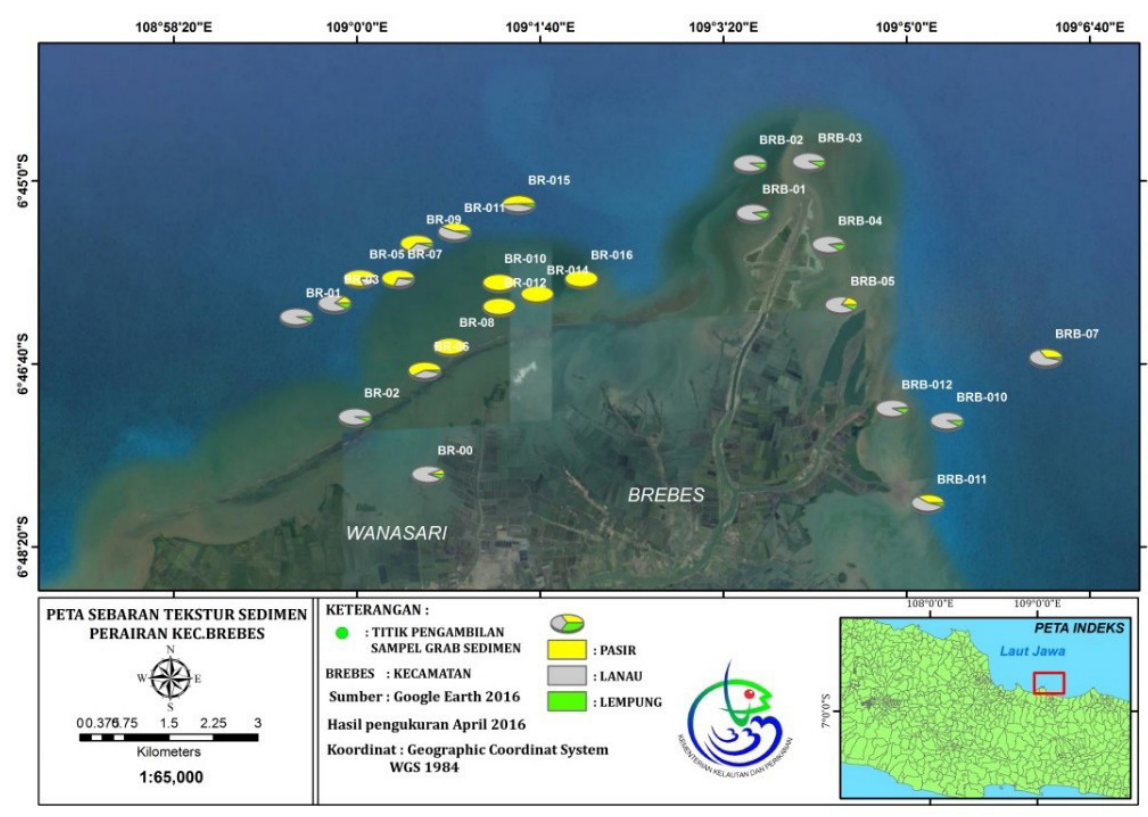

Gambar 3. Peta sebaran tekstur sedimen di perairan Kecamatan Brebes. Figure 3. Sediment texture distribution in Brebes coastal waters. 
pada muara Nipon berkisar antara 0,05-0,13 m/detik, rendahnya kecepatan arus pada kedua muara tersebut sangat mendukung bagi terendapkannya sedimen yang awalnya berasal dari input sungai Pemali dan Nipon (Gemilang et al., 2017).

Perbedaan ukuran butir sedimen berhubungan dengan asal sumber sedimen. Semakin kearah daratan atau dekat dengan muara sungai dan kawasan mangrove ukuran butir sedimen cenderung semakin halus, sedangkan ukuran butir yang berhadapan dengan laut lepas dan jauh dari muara sungai ukuran butir lebih kasar. Hal ini menunjukkan bahwa sumber sedimen berasal dari laut yang kemudian mengalami proses transportasi hingga akhirnya terendapkan menjadi sedimen di masing-masing lokasi. Selain itu ukuran butir lebih kasar diinterpretasikan merupakan hasil penggerusan beting gisik (pulau pasir) oleh gelombang kemudian tertransport pada bagian depan dasar perairan Kecamatan Brebes.

Kondisi menghalusnya butir sedimen menuju arah pesisir, dikarenakan adanya pengaruh periodisitas monsun di Laut Jawa. Pengambilan sampel sedimen masuk dalam periode monsun peralihan I yang ditandai dengan pola angin melemah dan memiliki arah yang tidak tentu (Siregar et al., 2015). Pola energi angin yang melemah tersebut yang menyebabkan kecenderungan ukuran butir sedimen menghalus menuju arah pesisir.
Selain itu menurut Davis (1991) arus sungai yang memasuki air laut akan mengalami perlambatan. Akibatnya kemampuan mengangkut material berkurang sehingga material tersebut mengendap pada bagian mulut muara dan depan muara sungai. Material sedimen yang berasal dari sungai didominasi ukuran halus, sehingga area sekitar muara cenderung terendapkan sedimen berukuran halus seperti lanau. Kondisi pasang surut yang terjadi di perairan Brebes dengan tipe pasang surut campuran harian ganda, dalam 24 jam terjadi hampir 2 kali pasang dan 2 kali surut dengan rentang yang berbeda. Kondisi tersebut menyebabkan kecepatan arus pasut yang terjadi lebih variatif dan fluktuatif yang menyebabkan terjadinya perbedaan mekanisme pengangkutan dan pengendapan sedimen di setiap kondisi pasutnya (Hoekstra et al., 2002).

Kecenderungan dominasi material sedimen halus pada perairan Brebes pada kondisi surut, dikarenakan elevasi sungai lebih tinggi, sehingga endapan sungai mendominasi. Berbeda pada saat kondisi pasang, elevasi maksimum muka air laut melebihi elevasi muka air sungai, sehingga material sedimen cenderung bercampur antara material halus dan kasar. Pengambilan sampel didominasi pada saat kondisi surut, sehingga dapat diinterpretasikan jenis sedimen depan muara sungai didominasi oleh ukuran sedimen lanau pasiran hingga lanau. Sedangkan pada daerah

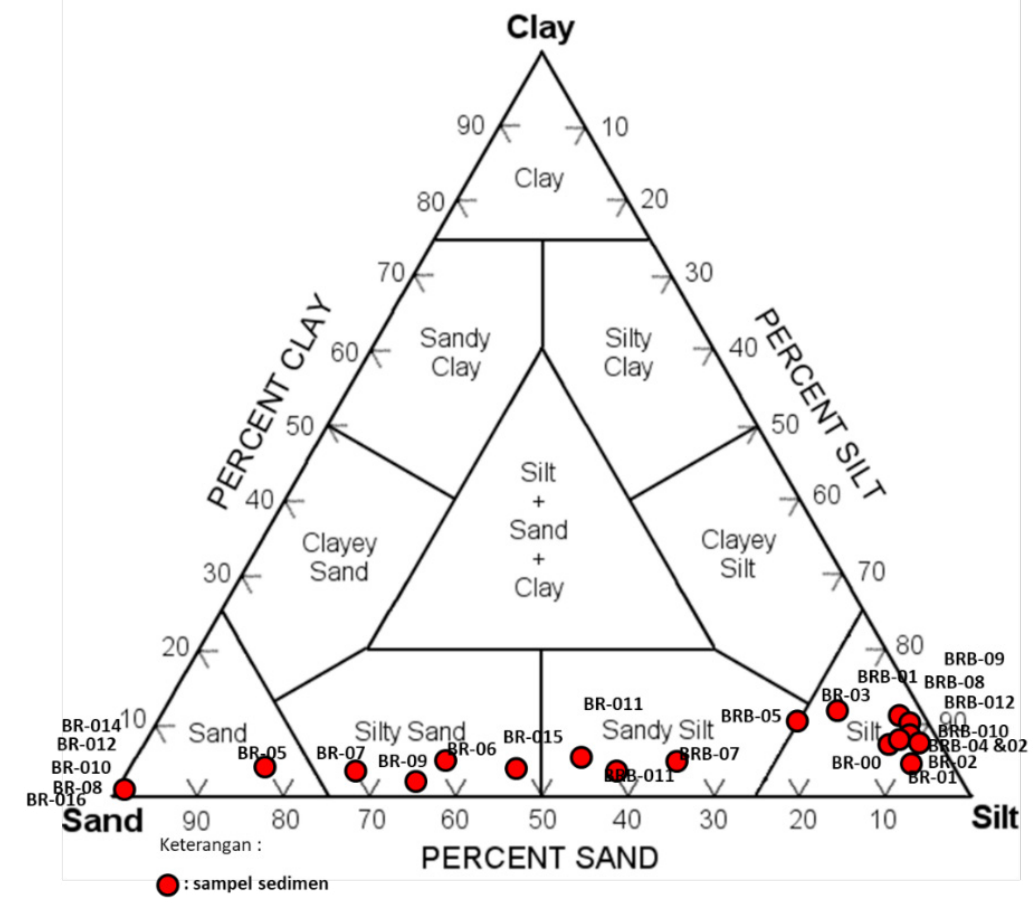

Gambar 4. Persentase dan jenis sedimen di perairan Kecamatan Brebes berdasarkan Diagram Segitiga Shepard 1954.

Figure 4. Sediment percentages and types in Brebes coastal waters according to Shepard 1954 triangle diagram. 
lain yang tidak berdekatan dengan muara didominasi oleh jenis endapan sedimen relatif lebih kasar berupa pasir lanauan - pasir.

\section{Interpretasi statistik ukuran butir sedimen}

Hasil perhitungan terhadap parameter statistik sedimen berupa sortasi menunjukkan nilai 0,54 - 1,91 sehingga masuk dalam klasifikasi tingkat pemilahan buruk hingga terpilah sedang (Folk \& Ward, 1977) (Tabel 1). Nilai sortasi sedimen di lokasi penelitian termasuk dalam pemilahan buruk hingga sedang, Ingmanson \& Wallace (1989) menjelaskan bahwa sedimen dengan granulometri terpilah buruk diakibatkan oleh ukuran partikel yang terakumulasi secara acak.

Kondisi pemilahan butiran sedimen buruk dipengaruhi oleh kekuatan arus dan gelombang sangat tidak stabil, artinya kekuatannya tidak sama setiap saat sehingga butiran sedimen yang diendapkan berbeda sangat mencolok (Rifardi, 2012). Selain kondisi tersebut proses pertemuan antara arus sungai dengan arus laut menyebabkan terjadinya gradasi energi arus pengendapan sehingga menyebabkan kondisi energi arus yang fluktuatif dan ukuran butir sedimen tidak terpilah dengan baik.

Nilai kemencengan (skewness) pada 26 sampel sedimen dasar perairan Kecamatan Brebes menunjukkan variasi nilai yang berbeda-beda dengan kisaran -0,82 - 0,89. Sehingga berdasarkan klasifikasi kemencengan daerah penelitian memiliki 5 jenis klasifikasi tingkat kemencengan butiran sedimen yaitu menceng halus, menceng simetris, menceng sangat halus, menceng sangat kasar dan menceng kasar. Hal ini menunjukkan bahwa sedimen telah mengalami proses transportasi dan mengendap pada kawasan perairan tersebut. Nilai kemencengan (skewness) yang didapat dari hasil perhitungan menunjukkan perbedaan tekstur sedimen antara stasiun.

Perbedaan nilai kemencengan menggambarkan kekuatan energi yang bekerja di perairan tersebut tidak dominan sama, atau berubah-ubah (Arjenggi et al., 2013). Kondisi skewnees/kemencengan secara umum pada daerah penelitian masuk dalam kondisi positively

Tabel 1. Luasan sebaran sedimentasi

Table 1. Extent of Sedimentation Distribution

\begin{tabular}{|c|c|c|c|c|c|c|}
\hline \multirow{2}{*}{$\begin{array}{l}\text { Kode Stasiun } \\
\text { BR-00 }\end{array}$} & \multirow{2}{*}{$\begin{array}{c}\text { Sortasi } \\
1,18\end{array}$} & \multirow{2}{*}{$\begin{array}{l}\text { Klasifikasi } \\
\text { Terpilah buruk }\end{array}$} & \multirow{2}{*}{$\begin{array}{l}\text { Skewness } \\
0,2\end{array}$} & \multirow{2}{*}{$\begin{array}{l}\text { Klasifikasi } \\
\text { Menceng halus }\end{array}$} & \multicolumn{2}{|c|}{ Kurtosis Klasifikasi } \\
\hline & & & & & 3,06 & Sangat runcing sekali \\
\hline BR-01 & 1,32 & Terpilah buruk & 0,18 & Menceng halus & 2,72 & Sangat runcing \\
\hline BR-02 & 1,03 & Terpilah buruk & 0,13 & Menceng halus & 3,3 & Sangat runcing sekali \\
\hline BR-03 & 1,78 & Terpilah buruk & $-0,07$ & Menceng simetris & 2,48 & Sangat runcing \\
\hline BR-05 & 1,03 & Terpilah buruk & 0,3 & Menceng sangat halus & 7,48 & Sangat runcing sekali \\
\hline BR-06 & 1,46 & Terpilah buruk & 0,43 & Menceng sangat halus & 3,84 & Sangat runcing sekali \\
\hline BR-07 & 1,38 & Terpilah buruk & 0,54 & Menceng sangat halus & 4,68 & Sangat runcing sekali \\
\hline BR-08 & 0,74 & Terpilah sedang & 0,06 & Menceng simetris & 4,76 & Sangat runcing sekali \\
\hline BR-09 & 1,78 & Terpilah buruk & 0,56 & Menceng sangat halus & 3,09 & Sangat runcing sekali \\
\hline BR-010 & 0,93 & Terpilah sedang & $-0,38$ & Menceng sangat kasar & 3,31 & Sangat runcing sekali \\
\hline BR-011 & 1,71 & Terpilah buruk & 0,18 & Menceng halus & 2,18 & Sangat runcing \\
\hline BR-012 & 0,54 & Terpilah sedang & $-0,17$ & Menceng kasar & 6,53 & Sangat runcing sekali \\
\hline BR-014 & 0,66 & Terpilah sedang & $-0,55$ & Menceng sangat kasar & 9,2 & Sangat runcing sekali \\
\hline BR-015 & 1,5 & Terpilah buruk & 0,16 & Menceng halus & 2,7 & Sangat runcing \\
\hline BR-016 & 0,54 & Terpilah sedang & $-0,17$ & Menceng kasar & 5 & Sangat runcing sekali \\
\hline BRB-01 & 1,1 & Terpilah buruk & 0,89 & Menceng sangat halus & 3,51 & Sangat runcing sekali \\
\hline BRB-02 & 0,99 & Terpilah sedang & $-0,82$ & Menceng sangat kasar & 3,03 & Sangat runcing sekali \\
\hline BRB-03 & 1,31 & Terpilah buruk & 0,32 & Menceng sangat halus & 2,6 & Sangat runcing \\
\hline BRB-04 & 1,31 & Terpilah buruk & $-0,01$ & Menceng simetris & 2,87 & Sangat runcing \\
\hline BRB-05 & 1,66 & Terpilah buruk & $-0,06$ & Menceng simetris & 2,37 & Sangat runcing \\
\hline BRB-07 & 0,86 & Terpilah sedang & 0,44 & Menceng sangat halus & 6,24 & Sangat runcing sekali \\
\hline BRB-08 & 1,33 & Terpilah buruk & 0,19 & Menceng halus & 2,62 & Sangat runcing \\
\hline BRB-09 & 1,17 & Terpilah buruk & $-0,2$ & Menceng kasar & 2,71 & Sangat runcing \\
\hline BRB-010 & 1,23 & Terpilah buruk & 0,14 & Menceng halus & 2,49 & Sangat runcing \\
\hline BRB-011 & 1,79 & Terpilah buruk & 0,01 & Menceng simetris & 2,18 & Sangat runcing \\
\hline BRB-012 & 1,35 & Terpilah buruk & 0,01 & Menceng simetris & 2,81 & Sangat runcing \\
\hline
\end{tabular}

JURNAL KELAUTAN NASIONAL, Vol. 13, No 2, Agustus 2018, Hal. 65-74 
skewed atau condong positif yang mengindikasikan bahwa kondisi di lokasi berada pada substrat berukuran halus yaitu lanau hingga lumpur dimana hal tersebut ditemukan dalam Surbakti (2010), bahwa skewness pada muara sungai berada pada kisaran rata-rata simetris, halus, hingga sangat halus. Nilai statistik sedimen berupa kurtosis menurut Darlan (1996) adalah gambaran hubungan sortasi bagian tengah dan bagian bawah dan hanya menunjukkan kriteria sedimen melalui grafik. Berdasarkan hasil perhitungan statistik sedimen nilai kurtosis daerah penelitian terdapat 2 jenis grafik kurtosis yaitu sangat runcing sekali dan sangat runcing.

\section{Mekanisme Sistem Pengendapan Sedimen}

Proses pengendapan sedimen di perairan Kecamatan Brebes dapat diperkirakan berdasarkan data hasil analisis granulometri dan statistik sedimen. Karakteristik ukuran butir sedimen digunakan untuk menafsirkan sebaran dan mekanisme pengangkutan dan pengendapan sedimen di suatu kawasan (Korwa et al., 2013). Secara umum jenis sedimen daerah penelitian di dominasi oleh partikel ukuran butir halus yaitu lanau hingga kasar (pasir). Berdasarkan ukuran butir sedimen tersebut menggambarkan bahwa kondisi perairan pada Kecamatan Brebes saat sedimen tersebut mengendap di pengaruhi oleh kecepatan arus kuat dicirikan dengan ukuran partikel kasar, sedangkan partikel ukuran halus dicirikan oleh arus yang lemah. Ukuran butir merupakan indikasi besar/ kuatnya kekuatan arus dan gelombang yang bekerja pada lingkungan pengendapan tersebut (Rifardi et al., 1998). Nilai sortasi mengindikasikan tipe pengendapan, karakteristik arus pengendapan dan kecepatan waktu pengendapan (Solahudin et al., 2006). Sedimen yang tersebar dan diendapkan di perairan daerah penelitian menunjukkan bahwa sedimen memiliki waktu yang pendek untuk mengendap ditunjukkan dengan tingginya nilai sortasi (terpilah buruk hingga sedang) menunjukkan keseragaman butir sedimen yang kecil.

Ukuran butir sedimen daerah penelitian masuk dalam fraksi kasar hingga halus sehingga dapat diinterpretasikan bahwa jenis mekanisme transportasi sedimen berupa bedload dan suspension (suspense). Mekanisme transportasi bedload terjadi pada fraksi yang kasar melalui pergerakan transportasi arus traksi dalam bentuk rolling (menggelinding), sliding (terseret), creep (merayap) dan siltasi. Suspension load bekerja mentranspor sedimen halus (lempung, lanau hingga pasir sangat halus) berbentuk suspensi yang terangkut cukup jauh dalam aliran, sebelum pada akhirnya mengendap dengan kecepatan arus yang melemah (Nugroho, 2014). Kondisi perairan laut Kecamatan Brebes sangat dipengaruhi oleh keberadaan

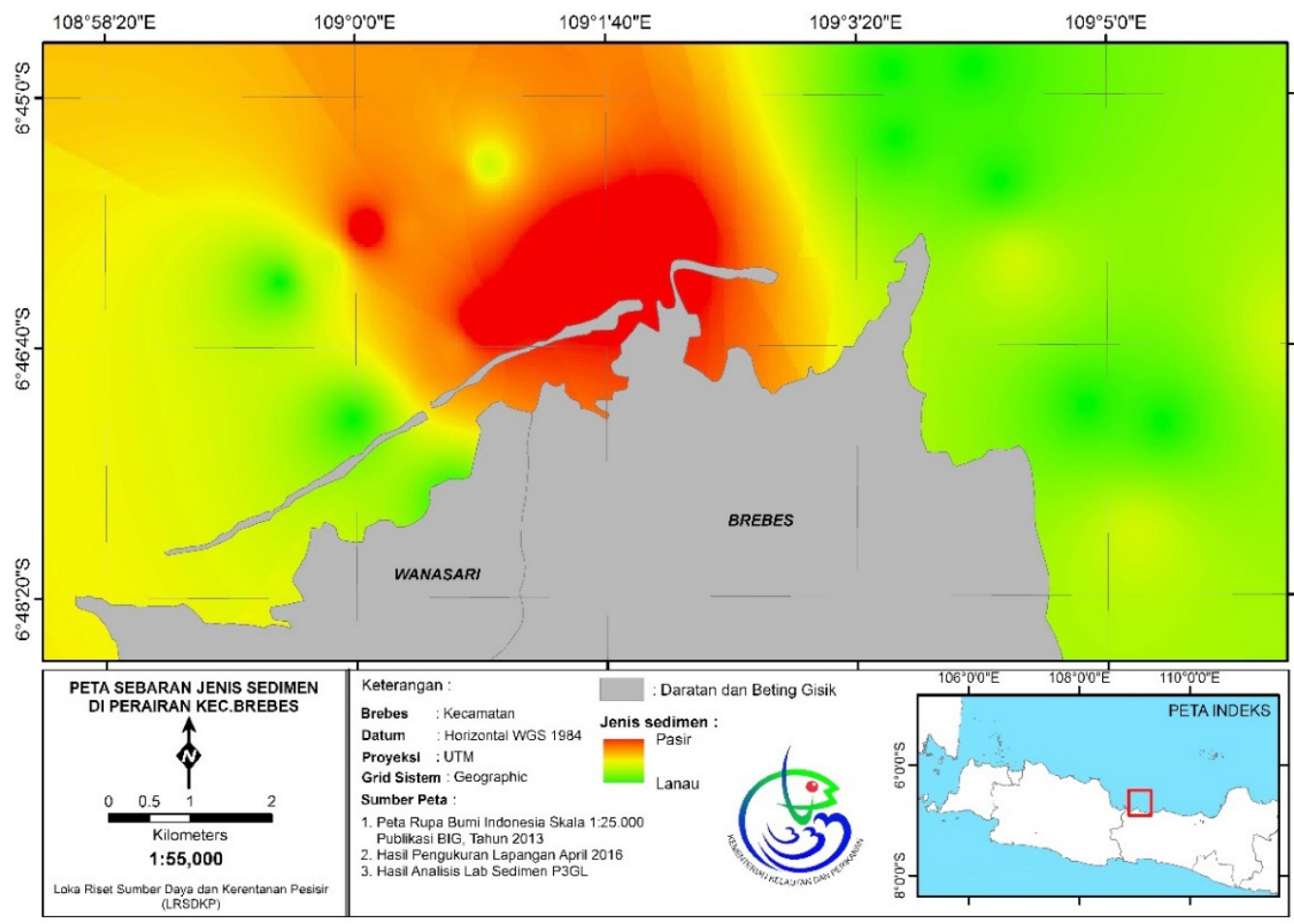

Gambar 5. Peta sebaran jenis sedimen di perairan Kecamatan Brebes.

Figure 5. Sediment type distribution in Brebes coastal waters. 
muara sungai, dimana muara sungai sangat dipengaruhi oleh kondisi debit sungai dan pasang-surut air laut. Disaat kondisi pasang energi arus sungai yang bertemu dengan air laut akan melemah dibagian muara sehingga tercampur endapan sungai dengan endapan laut dengan fraksi sedimen kasar. Namun disaat kondisi surut dan arus sungai melemah di bagian muara sehingga hanya fraksi halus berukuran lempung hingga lanau yang akan terendapkan. Sehingga pada bagian Timur daerah penelitian cenderung terendapkan sedimen halus lanau - lanau pasir (Gambar 5). Bagian Barat terendapkan material sedimen berukuran lebih kasar yaitu pasir hingga pasir lanauan. Kondisi tersebarnya ukuran butir lebih kasar menuju laut terbuka juga berpotensi membawa dampak semakin terjadinya proses pengikisan di daerah pantai (Bayhaqi \& Caesar, 2015), dalam kasus ini terjadi pengikisan pada daerah beting gisik (pulau pasir) yang ada di daerah penelitian.

Adanya sedimen berukuran kasar menunjukkan bahwa arus dan gelombang pada daerah ini relatif kuat, fraksi kasar yang tersebar pada bagian Barat daerah penelitian umumnya diendapkan pada daerah terbuka yang berhubungan dengan laut lepas, sedangkan sedimen halus diendapkan pada arus dan gelombang dengan energi lemah dan tenang yaitu pada bagian dekat darat dan muara sungai. Pada bagian Timur dan bagian Barat yang berdekatan dengan muara sungai didominasi oleh jenis sedimen lanau - lanau pasiran. Hal ini disebabkan karena letaknya yang lebih jauh dari lautan lepas dan terlindung dari pengaruh arus yang kuat serta banyak bahan organik dan detritus yang dibawa air sungai dan menumpuk di perairan ini, terutama pada saat arus melemah yang disebabkan oleh keberadaan kawasan mangrove.

Kawasan pesisir Kecamatan Brebes memiliki kawasan mangrove yang sangat luas, kondisi tersebut yang menjadi salah satu faktor mengurangi kecepatan arus dan gelombang sehingga dekat kawasan tersebut hanya terendapkan fraksi berukuran halus. Perbedaan tingkat kerapatan vegetasi mangrove akan menyebabkan perbedaan kecepatan arus akibat kemampuan perakaran mangroveyangmempumengakumulasiataumerangkap sedimen (Roza, 2016). Menurut Kennish (2000), perakaran mangrove yang mampu mengakumulasi sedimen, merangkap serasah dan berperan dalam pembentukan formasi tanah. Selanjutnya Nontji (2002) menambahkan bahwa ekosistem mangrove memiliki akar-akar yang kokoh dan dapat meredam pengaruh gelombang serta menahan lumpur atau sedimen halus sehingga lahan mangrove bisa menjadi semakin luas serta mempercepat terbentuknya tanah atau endapan sedimen untuk ditumbuhi mangrove.

\section{KESIMPULAN DAN SARAN}

Jenis sedimen berdasarkan hasil analisis granulometri terhadap sampel sedimen dasar perairan di Kecamatan Brebes terdapat 4 jenis sedimen menurut ukuran butirnya yaitu pasir, pasir lanauan, lanau pasiran dan lanau. Sebaran sedimen bagian Timur daerah penelitian didominasi oleh fraksi halus berupa lanau hingga lanau pasiran, sedangkan bagian Barat daerah penelitian didominasi oleh fraksi kasar, pasir hingga pasir lanauan. Kondisi hidro-oseanografi daerah penelitian mencirikan bahwa arus dan gelombang sangat fluktuatif sehingga terekam dalam klasifikasi sortasi butiran yang masuk dalam kelas pemilahan buruk hingga sedang. Mekanisme transportasi sedimen pada fraksi halus (lempung sampai lanau pasiran) tertranspor secara suspension load dalam bentuk suspensi.

Penelitian lebih lanjut terkait proses mekanisme sistem pengendapan sedimen di kawasan pesisir Kec. Brebes perlu dilakukan untuk mengetahui kondisi dan mekanisme transport sedimen pada beberapa musim sehingga diharapkan dapat menjadi bahan masukan dalam upaya mengurangi bencana erosi yang terjadi.

\section{UCAPAN TERIMA KASIH}

Penulis menyampaikan terima kasih kepada Loka Riset Sumber Daya dan Kerentanan Pesisir (LRSDKP) Balitbang KP atas DIPA Anggaran Penelitian tahun 2016 terkait penelitian yang dilakukan di Kecamatan Brebes dan reanalisis data dilakukan pada tahun 2017. Serta ucapan terima kasih kepada DKP Kab.Brebes dan Kelompok Mangrove Pandansari yang telah membantu dalam proses pengambilan data di lapangan. Ucapan terima kasih juga kami sampaikan kepada pihak-pihak yang telah bersedia memberikan koreksi, kritik, saran dan masukan sehingga peneliti dan penulisan ini dapat terselesaikan.

\section{DAFTAR PUSTAKA}

Abuodha J. O. Z. (2003). Grain size distribution and composition of modern dune and beach sediments, Malindi Bay coast, Kenya. Journal of African Earth Sciences 36: 41-54.

Apriyantoro, K., Saputro, S., \& Hariadi, H. (2016). Studi Sebaran Sedimen Dasar Di Perairan Muara Sungai Kluwut, Kabupaten Brebes, Jawa Tengah. Journal of Oceanography, 5(4), 435-440.

Ardani B. (2004). Pemantauan Dinamika Pesisir dengan 
Memanfaatkan Citra Satelit. Tesisis Sekolah Pasca Sarjana Institut Pertanian Bogor. Bogor: 197p.

Arjenggi, E. K., Muzahar \& Falmi, Y. (2013). Karakteristik Sedimen Permukaan Dasar di Perairan Kelurahan Tarempa Barat Kecamatan Siantan Kabupaten Anambas. Jurusan Ilmu Kelautan. Universitas Maritim Raja Ali Haji.

Bayhaqi, A \& Caesar M.A. Dungga. (2015). Distribusi butiran sedimen di pantai Dalegan, Gresik, Jawa Timur. Depik 4(3): 153-159p.

Blott J. S. \& Kenneth, P. (2001). Gradistat: A Grain Size Distribution and Statistics Packge For Analysis of Unconsolidated Sediments. Earth Surface Processes and Landforms 26: 1237-1248p.

Bui, E. N., Mazullo, J. \& Wilding, L. P. (1990). Using quartz grain size and shape analysis to distinguish between Aeolian and fluvial deposits in the Dallol Bosso of Niger (West Africa). Earth Surface Process and Landforms 14: 157-166.

Darlan, Y. (1996). Geomorfologi wilayah pesisir. Aplikasi untukpenelitian wilayah pantai. Pusat Pengembangan Geologi Kelautan. Bandung. 96p.

Davis, Jr. (1991). Oceanography: An Introduction to The Marine Enviroment. Wm.C. Brown Publisher. Lowa. USA. 516p.

Dinas Kelautan dan Perikanan Kabupaten Brebes. (2008). Penyusunan Rencana Tata Ruang Pesisir Kabupaten Brebes. 56p.

Dinas Kelautan dan Perikanan Propinsi Jawa Tengah. (2012). Penyusunan Rencana Zonasi Wilayah Pesisir dan Pulau-Pulau Kecil (RZWP3K) Provinsi Jawa Tengah. $135 \mathrm{p}$.

Djuri, M., Samodra, H., Amin, T. C. \& Gafoer, S. (1996). Peta Geologi Lembar Purwokerto dan Tegal, Jawa. Pusat Penelitian dan Pengembangan Geologi. Bandung.

Dyer, K. (1986). Coastal and estuarine sediment dynamics. John Wiley and Sons. Chichester. 324p.

Folk, R. I. \& Ward, W. C. (1957). Brazos River bar: a study in the significance of grain size parameters. Journal of Sedimentary Petrology 27; 3-26p.

Folk, R. L. \& Ward, P. B. (1977). Student operator error in determination of roundess, spherity and grain size. Sed Petrology. 25: 297-301p.

Friedman, G. M. (1979). Differences in size distrobutions of populatioms of particles among sands of various origins. Sedimentology 26: 3-32p.

Ganesh, B., Naidu, A.G.S.S., Jagannadha Rao, M., Karuna Karudu, T. \& Avatharam, P. (2013). Studies on textural characteristics of sediments from Gosthani River Estuary - Bheemunipatnam, A.P., East Coast of India. J.Ind. Geophys.Union 17(2): 139-151p.

Gemilang, W. A., Kusumah, G., Wisha, U. J., \& Arman, A. (2017). Laju Sedimentasi Di Perairan Brebes, Jawa Tengah Menggunakan Metode Isotop 210pb. Jurnal Geologi Kelautan, 15(1).

Hoekstra, P., Lindeboom, H., Bak, R., Bergh, G. V. D., Tiwi, D. A., Douven, W. et al. (2002). Teluk Banten Research
Programme: an integrated coastal zone management Study. Staple (Ed.) Scientific programme IndonesiaNetherlands Proceedings of a workshop held on February 12th2002. Bandung. Indonesia. p, 59-70.

Hsieh, H. (1995). Spatial and temporal patterns of polychaete communities in a subtropical mangrove swamp: infulences of sediment and microhabitat. Mar Ecol Prog Ser., 127:157-167.

Hubbard, J. A. E. B. \& Pocock, Y. P. (1972). Sediment rejection by recent scleractinian corals: a key to paleon environmental reconstruction. Geologische Rundsehau, 61:598-626p.

Ingmanson D. E. \& Wallace, W. J. (1989). Oceanography an Introduction. Fouth Edition. Wadsworth Publishing Company. Belmont, California. 541p.

Kennish, M. J. (2000). Estuary Restoration and Maintenance: The National Estuary Programe. Boca Raton. USA: CRC.

Korwa J. I. S., Opa, E. T. \& Djamaludin, R. (2013). Karakteristik Sedimen Litoral di Pantai Sindualang Satu. Jurnal Pesisir dan Laut Tropis, 1(1):48-58.

McLaren, P. \& Bowles, D. (1985). The Effects of Sediment Transport on Grain-Size Distributions. Journal of Sedimentary Petrology 55 (4): 457-470p.

Nontji, A. (2002). Laut Nusantara. Jakarta (ID): Djambatan Pr.

Nugroho, S. H. \& Basit, A. (2014). Sebaran Sedimen Berdasarkan Analisis Ukuran Butir Di Teluk Weda, Maluku Utara. Jurnal Ilmu dan Teknologi Kelautan Tropis 6 (1): 229-240p.

Purnawan, S., Setiawan, I. \& Marwantim. (2012). Studi sebaran sedimen berdasarkan ukuran butir di perairan Kuala Gigieng, Kabupaten Aceh Besar, Provinsi Aceh. Depik, 1(1):31-36p.

Rainey M. P., Tyler, A. N., Gilver, D. J., Bryant, R. G. \& McDonald, P. (2003). Mapping intertidal estuarine sediment grain size distributions through airbone remote sensing. Elsevier (Remote Sensing of Enviroment, (86): 480-490.

Rifardi, O. K. \& Tomiyasu, T. (1998). Sedimentary Environments Based on Texture Surface Sediments and Sedimentation Rates in the South Yatsushiro (Sea), Soutwest Kyushu, Japan. Jour. Sedimentol. Soc. Japan (48):67-84.

Rifardi. (2012). Geologi Sedimen Modern (Edisirevisi). Universitas Riau Press.

Roza, S. Y. (2016). Kontribusi Mangrove Dalam Memerangkap Sedimen Di Wilayah Pesisir Kota Dumai Provinsi Riau (tesis). Bogor. Institus Pertanian Bogor.

Shepard F. P. (1954). Nomenclature based on sand-silt-clay ratios. J. of Sedimentary Petrology, 24(3):151-158p.

Siregar, S. N., Sari, L. P., Purba, N. P., Pranowo, W. S., \& Syamsuddin, M. L. (2017). Pertukaran massa air di Laut Jawa terhadap periodisitas monsun dan Arlindo pada tahun 2015. DEPIK Jurnal Ilmu-Ilmu Perairan, Pesisir dan Perikanan, 6(1), 44-59.

Solahuddin, T., Triarso, E. \& Troa, R.A. (2006). Karaktersistik 
tekstur sedimen berdasarkan analisis granulometri dan morfologi batupasir sepanjang Sungai Progo di Daerah Kalibawang-Pantai Trisik. D.I.Y. Proceddings of International Conference on Earth Science and Technology Vol I.

Surbakti, H. (2010). Pemodelan sebaran sedimen tersuspensi dan pola arus di pesisir Banyuasin, Sumatera Selatan (tesis). Bogor: Institut Pertanian Bogor.

Wenno, L. F. \& Y. Witasari. (2001). Distribusi ukuran butir pasir di Pantai Parangtritis, Yogyakarta. Pesisir dan Pantai Indonesia, 6:95-103p.

Wentworth, C. K. (1922). A scale of grade and class term for clastic sediment. J. Geology, 30:337-392p.

Winter, C. (2007). On the evaluation of sediment transport models in tidal environments. Sedimentary Geology, 202:562-571. Doi:101016/j. sedgeo.2007.03.019.

Yasin, A. M., Sukiyah, E. \& Isnaniawardhani, V. (2016). Grain Size Analysis of Quartenary Sediment from Kendari Basin, Indonesia. International Journal of Science and Research (IJSR): 2139-7064p. 